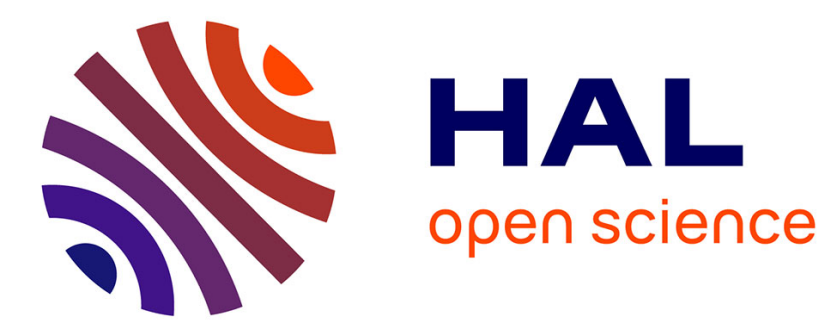

\title{
p11 modulates calcium handling through 5-HT4R pathway in rat ventricular cardiomyocytes
}

Pierre Meschin, Marie Demion, Olivier Cazorla, Amanda Finan, Jérôme Thireau, Sylvain Richard, Alain Lacampagne

\section{To cite this version:}

Pierre Meschin, Marie Demion, Olivier Cazorla, Amanda Finan, Jérôme Thireau, et al.. p11 modulates calcium handling through 5-HT4R pathway in rat ventricular cardiomyocytes. Cell Calcium, 2015, 58 (6), pp.549 - 557. 10.1016/j.ceca.2015.08.005 . hal-01761263

\section{HAL Id: hal-01761263 \\ https://hal.umontpellier.fr/hal-01761263}

Submitted on 7 Nov 2018

HAL is a multi-disciplinary open access archive for the deposit and dissemination of scientific research documents, whether they are published or not. The documents may come from teaching and research institutions in France or abroad, or from public or private research centers.
L'archive ouverte pluridisciplinaire HAL, est destinée au dépôt et à la diffusion de documents scientifiques de niveau recherche, publiés ou non, émanant des établissements d'enseignement et de recherche français ou étrangers, des laboratoires publics ou privés. 


\title{
p11 modulates calcium handling through $5-\mathrm{HT}_{4} \mathrm{R}$ pathway in rat ventricular cardiomyocytes
}

\author{
Pierre Meschin, Marie Demion ${ }^{1}$, Olivier Cazorla ${ }^{1}$, Amanda Finan, Jérôme Thireau, \\ Sylvain Richard*, Alain Lacampagne **
}

PHYMEDEXP, Physiologie et Médecine Expérimentale du Coeur et des Muscles, INSERM U1046, CNRS UMR-9214, Université Montpellier, CHU Arnaud de Villeneuve, 371 avenue du doyen Gaston Giraud, 34295 Montpellier cedex, France

Keywords:

Serotonin receptor 4

S100A10

Calcium waves

Brain-derived neurotrophic factor

Antidepressant

\begin{abstract}
A B S T R A C T
Background: The role of the serotonin receptor $4\left(5-\mathrm{HT}_{4} \mathrm{R}\right)$ pathway in cardiac excitation-contraction coupling (ECC) remains unclear. In the brain, induction of the calcium $\left(\mathrm{Ca}^{2+}\right)$-binding protein p11 enhances $5-\mathrm{HT}_{4} \mathrm{R}$ translocation and signaling and could therefore be considered as a modulator of the $5-\mathrm{HT}_{4} \mathrm{R}$ pathway in the myocardium. p11 expression is increased by brain-derived neurotrophic factor (BDNF) or antidepressant drugs (imipramine). Thus, we investigated whether $\mathrm{p} 11$ regulates the $5-\mathrm{HT}_{4} \mathrm{R}$ pathway in the heart in physiological conditions or under pharmacological induction and the effects on calcium handling.

Methods and results: p11 expression was induced in vivo in healthy Wistar rats by imipramine $(10 \mathrm{mg} / \mathrm{kg} / 21$ days) and in vitro in left ventricular cardiomyocytes exposed to BDNF (50 ng/ml/8 h). Cell shortening and real-time $\mathrm{Ca}^{2+}$ measurements were processed on field-stimulated intact cardiomyocytes with the selective $5-\mathrm{HT}_{4} \mathrm{R}$ agonist, prucalopride $(1 \mu \mathrm{M})$. Both imipramine and BDNF-induced cardiomyocyte p11 expression unmasked a strong response to prucalopride characterized by an increase of both cell shortening and $\mathrm{Ca}^{2+}$ transient amplitude compared to basal prucalopride associated with a high propensity to trigger diastolic $\mathrm{Ca}^{2+}$ events. Healthy rats treated with BDNF (180 ng/day/14 days) exhibited a sustained elevated heart rate following a single injection of prucalopride $(0.1 \mathrm{mg} / \mathrm{kg}) \mathrm{which}$ was not observed prior to treatment.

Conclusions: We have identified a novel role for $\mathrm{p} 11$ in $5-\mathrm{HT}_{4} \mathrm{R}$ signaling in healthy rat ventricular cardiomyocytes. Increased p11 expression by BDNF and imipramine unraveled a 5-HT4 R-mediated modulation of cardiac $\mathrm{Ca}^{2+}$ handling and ECC associated with deleterious $\mathrm{Ca}^{2+}$ flux disturbances. Such mechanism could partly explain some cardiac adverse effects induced by antidepressant treatments.
\end{abstract}

\section{Introduction}

Cardiac activity is mainly dependent on calcium $\left(\mathrm{Ca}^{2+}\right)$ cycling and tightly regulated by the autonomic nervous system and chronic disturbances of these two factors may lead to major cardiac dysfunction $[1,2]$. In addition to catecholamines,

\footnotetext{
* Corresponding author at: CHU Arnaud de Villeneuve, 371 avenue du doyen G. Giraud, 34295 Montpellier cedex 5, France. Tel.: +33 4674152 40; fax: +33467415242.

** Corresponding author at: CHU Arnaud de Villeneuve, 371 avenue du doyen G. Giraud, 34295 Montpellier cedex 5, France. Tel.: +33 4674152 44; fax: +33467415242.

E-mail addresses: sylvain.richard@inserm.fr (S. Richard), alain.lacampagne@inserm.fr (A. Lacampagne).

1 Equal contribution.
}

serotonin (5-hydroxytryptamine [5-HT]) is involved in the physiology of the healthy [3] and pathologic human myocardium as described in heart failure [4] and atrial fibrillation where it promotes arrhythmogenicity [5,6]. Although 5-HT is likely to induce several well identified physiological cardiovascular effects in human and pig [4-6], it has been shown to be inactive on ventricular cardiomyocytes in rodents $[7,8]$. In the last decade, Qvigstad et al. proposed a new role for 5-HT in ventricles of rats with heart failure. Indeed, six weeks after myocardial infarction, 5-HT produced a positive inotropic effect through $\mathrm{G}_{\mathrm{s}}$-coupled serotonin receptor $4\left(5-\mathrm{HT}_{4} \mathrm{R}\right)$ activation $[9,10]$. Similarly to $\beta$ adrenergic receptors, $5-\mathrm{HT}_{4} \mathrm{R}$ stimulation increases cytoplasmic cAMP production through adenylate cyclase activity which promotes cAMP-dependent protein kinase A (PKA) activation. PKA phosphorylates key participants of $\mathrm{Ca}^{2+}$ handling hence positively enhancing cardiac excitation-contraction coupling (ECC) [1]. 
Consistent with this, $5-\mathrm{HT}_{4} \mathrm{R}$ activation has been shown to induce phosphorylation of L-type $\mathrm{Ca}^{2+}$ channels (LTCC), troponin I or phospholamban (PLB) in the failing rat heart [11].

In the mouse brain, $5-\mathrm{HT}_{4} \mathrm{R}$ interacts with a small $11 \mathrm{kDa}$ protein, p11 (or S100A10) which increases the translocation of the receptor to the plasma membrane improving $5-\mathrm{HT}_{4} \mathrm{R}$ signaling demonstrated by increased cAMP production [12]. p11 is a member of the $\mathrm{S} 100$ protein family which is the largest family of $\mathrm{Ca}^{2+}$ binding proteins. Nevertheless, unlike others S100 proteins, amino acid replacements in the p11 $\mathrm{Ca}^{2+}$-binding loops make it unable to bind $\mathrm{Ca}^{2+}$ but leads to a permanent activated state of p11 [13]. p11 is highly expressed in the lung, intestine and kidney but poorly in the heart [14] where its role has yet to be elucidated. In vessels, p11 is known to play a crucial role in the regulation of plasmin activity as a receptor for plasminogen and tissue-type plasminogen activator (tPA) [15] or in the secretion of endothelial von Willebrand factor [16]. Interestingly, p11 participation has emerged in the intracellular trafficking of several ion channels and G-protein coupled receptors such as transient receptor potential (TRP) channels [17] and sodium channels [18] or serotonin receptors such as $5-\mathrm{HT}_{1 \mathrm{~B}}$ [19] or as mentioned above, $5-\mathrm{HT}_{4} \mathrm{R}$. p11 expression is modulated by nitric oxide [20], transforming growth factor alpha (TGF $\alpha$ ) [21], nerve growth factor (NGF) [22] and brain-derived neurotrophic factor (BDNF) [23] or antidepressants drugs such as imipramine [19].

In the present work, we aimed to explore a potential role for p11 in the modulation of $5-\mathrm{HT}_{4} \mathrm{R}$ signaling at the ventricular level of healthy cardiac tissue. Assessment of p11 was conducted in basal conditions or after pharmacological induction. We have identified that p11 acts as a substantial modulator of ventricular cardiomyocyte $\mathrm{Ca}^{2+}$ handling and contractility through the $5-\mathrm{HT}_{4} \mathrm{R}$ pathway. Induction of p11 may be enhanced by factors used in depression treatment and is associated with proarrhythmogenic $\mathrm{Ca}^{2+}$ flux disturbances.

\section{Methods}

\subsection{Animals}

All procedures were carried out conforming to the Directive 2010/63/EU of the European Parliament and the Council of 22 September 2010 for the protection of animals used for scientific purposes (agreement number: A34-172-38). Animals were housed in a temperature-regulated room (12-h day:12-h night cycle) with access to food and water ad libitum. To induce in vivo p11 expression in adult healthy hearts, 200-224g male Wistar rats from Janvier (Le Genest-Saint-Isle, France) were subjected to either I) Subcutaneous BDNF treatment for 14 days (180 ng/day) (B3795, Sigma-Aldrich, St-Quentin-Fallavier, France) or II) Intraperitoneal injection of either Imipramine $(10 \mathrm{mg} / \mathrm{kg} / \mathrm{day})$ (I0899, SigmaAldrich, St-Quentin-Fallavier, France) or saline for 21 days (rats were sacrificed the day after the last injection). Subcutaneous treatment was achieved by the implantation of osmotic pumps (2ML2, Alzet, Charles River, l'Arbresle, France) under general gaseous anesthesia (2.5\% isoflurane (Isovet ${ }^{\circledR}$, Dechra Veterinary Products, Suresnes, France) in $100 \%$ oxygen) on a heating pad. Lidocaïne was applied on the wound after surgery.

\subsection{Electrocardiograms (ECG) telemetry}

ECG transmitters (CA-F40, Data Science International (DSI), St. Paul, Minnesota, USA) were intraabdominally implanted in rats placed on a heating table under general gaseous anesthesia $(2.5 \%$ isoflurane in $100 \%$ oxygen). Telemetric ECGs were recorded one week after surgery and analyzed in conscious free moving rats using a Ponemah physiology platform (DSI) to obtain heart rate and RR intervals as previously described [24]. To assess the cardiac effects of $5-\mathrm{HT}_{4} \mathrm{R}$ stimulation, healthy adults rats received a single intraperitoneal injection of the $5-\mathrm{HT}_{4} \mathrm{R}$ selective agonist prucalopride $(0.1 \mathrm{mg} / \mathrm{kg}$ in water) (A11771, AdooQ Biosciences, Irvine, California, USA) before and after subcutaneous treatment with BDNF (180 ng/day/14 days). ECGs recordings were started $60 \mathrm{~min}$ prior to prucalopride injections and stopped at the end of the nocturnal phase.

\subsection{Cell dissociation}

Experiments were performed at the single cell level using left ventricular free wall (LV-FW) cardiomyocytes that were enzymatically isolated as previously described [25]. Briefly, hearts were excised and cannulated through the aorta to a retrograde perfusion Langendorff system to remove the blood from the coronary arterial vasculature. Hearts were then perfused with a free $\mathrm{Ca}^{2+}$ physiological tyrode solution $\left(116 \mathrm{mM} \mathrm{NaCl}, 6 \mathrm{mM} \mathrm{KCl}, 4 \mathrm{mM} \mathrm{NaHCO}{ }_{3}\right.$ $1.5 \mathrm{mM} \mathrm{KH}_{2} \mathrm{PO}_{4}, 1.7 \mathrm{mM} \mathrm{MgCl}_{2}, 21 \mathrm{mM}$ HEPES, $20 \mathrm{mM}$ taurine and $12 \mathrm{mM}$ glucose, $\mathrm{pH} 7.15$ ) containing a permeant protease inhibitor (E-64d, $10 \mu \mathrm{M}$, E8640, Sigma-Aldrich, St-Quentin-Fallavier, France) at constant flow perfusion rate. Hearts were then perfused with type IV collagenase (Worthington, Entraigues, France) solution and left ventricular free walls were collected in a $\mathrm{Ca}^{2+}$ free solution, dissected and mechanically dissociated. The $\mathrm{Ca}^{2+}$ concentration was gradually increased to $1 \mathrm{mM}$ and cells were maintained in a physiological solution at $37^{\circ} \mathrm{C}$ for $30 \mathrm{~min}$ before further processing. To induce in vitro p11 expression, freshly isolated LV-FW myocytes were incubated with $50 \mathrm{ng} / \mathrm{ml} \mathrm{BDNF}$ for $8 \mathrm{~h}$ at $25^{\circ} \mathrm{C}$.

\subsection{Quantitative RT-PCR}

Total RNA was isolated from snap-frozen intact tissue or isolated LV-FW cardiomyocytes using a Nucleospin total RNA isolation kit (Macherey-Nagel, Hoerdt, France) according to the manufacturer's instructions. Total RNA, oligo-dT and random hexamer primers were used to generate cDNA using the Verso enzyme kit (Fisher Scientific, Illkirch, France). To evaluate p11 and 5- $\mathrm{HT}_{4} \mathrm{R}$ expressions, real time RT-PCR was performed using gene-specific primers. Reactions were performed using SYBR green master Mix (Roche Applied Sciences, Meylan, France). The Rpl32 gene expression was used as the housekeeping gene. Relative gene expression was determined by the $2^{-\Delta \Delta \mathrm{Ct}}$ method. Primers sequences were designed with the primer design tool from NCBI (NCBI/primer-BLAST) or as previously described [26,27]:

S100a10 (p11) FW: 5'-CGGGGCCCAGGTTTCGACAG-3'

ID: 81718 RV: 5'-CCCGTTCCATGAGCACTCTCAGGT-3'

Htr4 FW: 5'-GATGACCCCTCTACGCATCG-3'

ID: 25324 RV: 5'-AGCACCATGAGGAGAAACGG-3'

Rpl32 FW: 5'-CACCAGTCGGACCGATATGTGAAAA-3'

ID: 28298 RV: 5'-TGTTGTCGATGCCTCTGGGTTT-3'

\subsection{Protein analysis}

Proteins were extracted from snap-frozen intact tissue or isolated LV-FW cardiomyocytes with a manual polytron ${ }^{\circledR}$ homogenizer. Protein extracts were lysed in $200 \mu$ lysis buffer $(20 \mathrm{mM}$ HEPES, $40 \mathrm{mM} \mathrm{KCl}, 1 \mathrm{mM}$ DTT, $0.3 \%$ CHAPS, $1 \times$ protease inhibitor SigmaFAST) for $30 \mathrm{~min}$ at $4{ }^{\circ} \mathrm{C}$ with mixing. Proteins were then separated by SDS-PAGE, blotted onto nitrocellulose membranes ( $0.2 \mu \mathrm{m}$, GE Healthcare, Brumath, France) for $1 \mathrm{~h}$ and then blocked with StartingBlock (TBS) blocking buffer (37543, Fisher Scientific, Illkirch, France) for $2 \mathrm{~h}$ at room temperature. Membranes were incubated overnight at $4{ }^{\circ} \mathrm{C}$ with primary antibodies: p11 antibody $(1 / 1.000$, AF2377, R\&D systems, Lille, France) or $\beta 1$-adrenergic receptor (1/200, sc-568, Santa-Cruz, Heidelberg, Germany). Protein 
levels were expressed relative to GAPDH (1/60.000, ab8245, Abcam, Cambridge, UK) or Calsequestrin 2 (CASQ2) (1/2.500, PA1-913, Fisher Scientific, Illkirch, France) expressions. Experiments were repeated a minimum of three times for each condition. All immunoblots were visualized and quantified using the Odyssey ${ }^{\circledR}$ infrared imaging system (LI-COR Biosciences, Lincoln, Nebraska, USA) coupled to infrared-labeled anti-goat, anti-mouse or anti-rabbit IgG secondary antibodies (1/30,000 dilution) (LI-COR Biosciences, Courtaboeuf, France).

\subsection{Cellular $\mathrm{Ca}^{2+}$ transients and shortening measurements}

Real time $\mathrm{Ca}^{2+}$ measurements was performed on freshly isolated LV-FW myocytes incubated in a physiological tyrode solution (140 mM NaCl, 4 mM KCl, 1 mM MgCl 2,5 mM HEPES, $1.8 \mathrm{mM} \mathrm{CaCl}_{2}$ and $11 \mathrm{mM}$ glucose, $\mathrm{pH}$ 7.4). Cardiomyocytes were loaded with the ratiometric $\mathrm{Ca}^{2+}$ dye, indo-1AM at room temperature during $20 \mathrm{~min}$ ( $2 \mu \mathrm{M}$, Life technologies, St-Aubin, France) and cell shortening $/ \mathrm{Ca}^{2+}$ transients were recorded using electrical-field stimulation $(1 \mathrm{~Hz})$. Sarcomere length (SL) and fluorescence wavelengths emitted at $405 \mathrm{~nm}$ (F405) and $480 \mathrm{~nm}$ (F480) were simultaneously recorded using the IonOptix ${ }^{\circledR}$ system (Milton, USA) coupled to a Zeiss microscope $\left(40 \times\right.$ oil, $0.36 \mu \mathrm{m} /$ pixel) [24]. The approximate $\left[\mathrm{Ca}^{2+}\right]_{\text {cytosolic }}$ was obtained by measuring the ratio F405/F480. In all experiments, $5-\mathrm{HT}_{4} \mathrm{R}$ was stimulated by a $30 \mathrm{~min}$ incubation with the specific $5-\mathrm{HT}_{4} \mathrm{R}$ agonist, prucalopride $(1 \mu \mathrm{M})$, or blocked with a 30 min preincubation with the specific $5-\mathrm{HT}_{4} \mathrm{R}$ blocker GR113808 $(10 \mu \mathrm{M})$ (G5918, Sigma-Aldrich, St-Quentin-Fallavier, France) prior to prucalopride stimulation. $\mathrm{Ca}^{2+}$ waves defined by any spontaneous rise in the fluorescence ratio during the diastolic phase (30 s) were considered as proarrhythmogenic cellular activity. In all experiments, at least 10 cells were recorded per animal. Data were analyzed using IonWizard 6.4 software.

\subsection{Statistical analysis}

$N$ represents the number of animals and $n$ the number of cells. Data are presented as mean \pm SEM (or mean \pm SD for in vivo BDNF experiments). Statistical analyses were performed using SigmaStats 3.5 software. Student $t$-test was used to compare two conditions. For BDNF and imipramine experiments, two-way ANOVA was used to, respectively, compare multiple conditions. For paired values comparison, Wilcoxon signed-rank test was used. Fisher's exact test was used for percentages comparison. $P$-value lower or equal to 0.05 indicated a statistically significant difference.

\section{Results}

\subsection{Low expression of $p 11$ is associated with an inactive $5-H T_{4} R$ pathway in healthy LV-FW cardiomyocytes.}

The expression of p11 was investigated in different regions of the normal heart at the tissue and cellular levels and was compared to tissues known to express high levels of p11 expression such as the small intestine or the brain (Fig. 1). At the transcript level, p11 mRNA was detected by qualitative conventional RT-PCR in atrial and LV-FW tissue as well as in LV-FW single cardiomyocytes (Fig. 1A, upper panel). In the same tissues, 5- $\mathrm{HT}_{4} \mathrm{R}$ mRNA was also expressed but in a more modest pattern compared to the small intestine or the brain (Fig. 1A, lower panel). At the protein level, p11 was expressed in both total atrial and ventricular tissues and specifically in LV-FW cardiomyocytes (Fig. 1B, upper panel). It is worth noting that levels of p11 expression in the LV remained very low compared to tissues where p11 is known to be highly expressed or active (Fig. 1B, lower panel).p11 expression was higher in the atria than in the left ventricle where the $5-\mathrm{HT}_{4} \mathrm{R}$ pathway is
A.
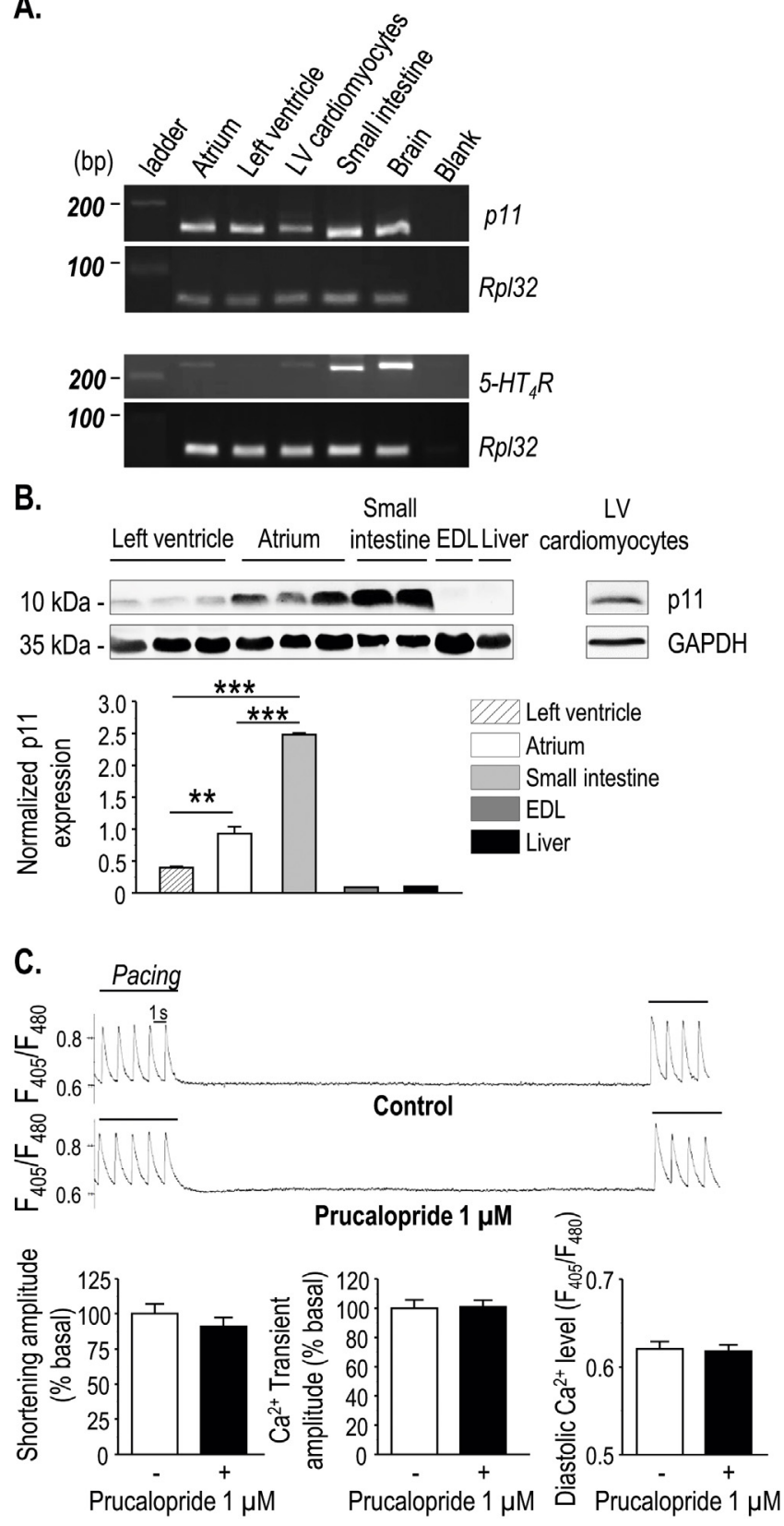

Fig. 1. Physiological p11 expression in cardiac tissue and $5-\mathrm{HT}_{4} \mathrm{R}$ signaling in healthy LV-FW cardiomyocytes. (A) Qualitative mRNA expression in atrium, left ventricle (LV) or adult LV-FW cardiomyocytes from healthy rats assessed by conventional RT-PCR with gene-specific primers for p11 (142 basepair [bp]) (upper panel) or $5-H T_{4} R$ (234 bp) (lower panel). The small intestine and the brain served as a positive controls for p11 and 5- $\mathrm{HT}_{4} \mathrm{R}$ mRNA expression. Rpl32 gene (64 bp) served as the housekeeping gene (presented samples for $\mathrm{p} 11$ or $5-\mathrm{HT}_{4} \mathrm{R}$ mRNA are extracted from the same experiment). (B) p11 protein expression quantified in atrium $(N=3), \operatorname{LV}(N=3)$ and LV-FW cardiomyocytes from healthy rats assessed by Western blot. The small intestine $(N=2)$ served as a positive control and both the skeletal muscle (Extensus Digitorium Longus [EDL]) $(N=1)$ /the liver $(N=1)$ as negative controls for p11 protein expression. (C, upper panel) Representative traces of indo-1AM ratio obtained in basal condition or with prucalopride $(1 \mu \mathrm{M})$ in fieldstimulated healthy freshly isolated LV-FW cardiomyocytes. (C, lower panels) Effect of prucalopride $(1 \mu \mathrm{M})$ on SL shortening (lower left panel), $\mathrm{Ca}^{2+}$ transient amplitude (lower middle panel) and diastolic $\mathrm{Ca}^{2+}$ level (lower right panel) in field-stimulated intact LV-FW cardiomyocytes. $N$ stands for the number of animals and $n$ for the number of cells: $N=3$, respectively, $n=29$ and $n=30$. White bars represent the basal condition and the black bars, the prucalopride stimulation. Data are presented as mean \pm SEM. ${ }^{* * * * * *} p<0.01, p<0.001$. 
A.

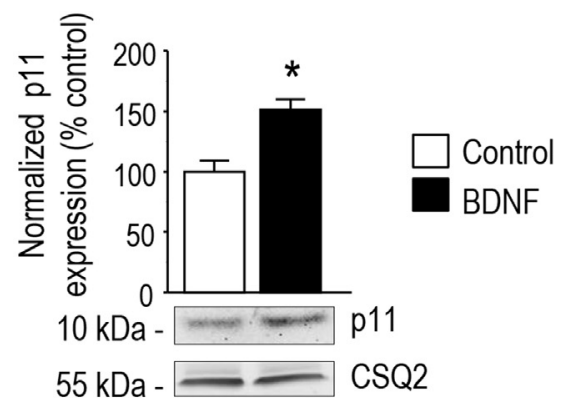

B.
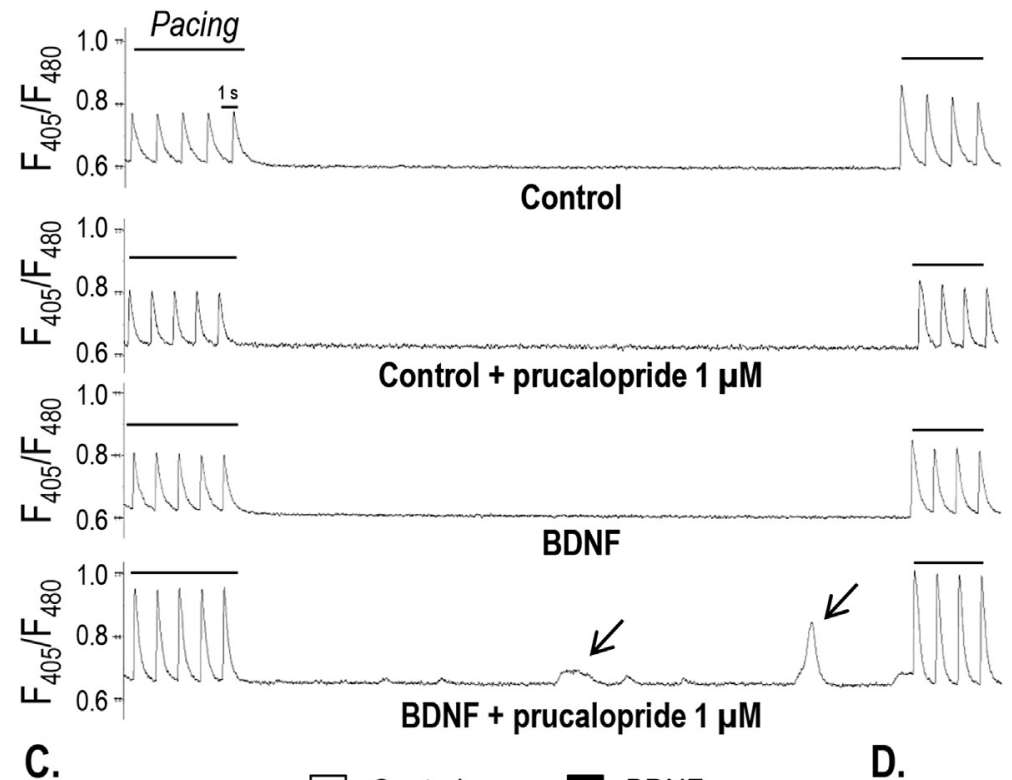

C.

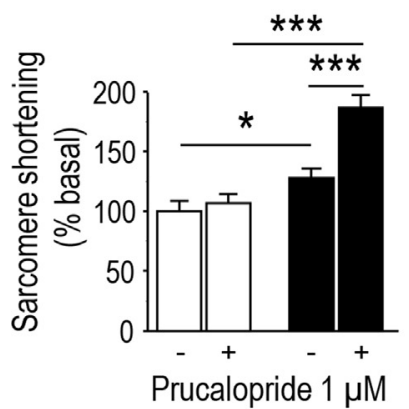

E.

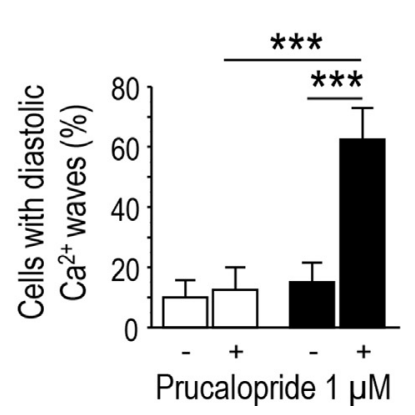

Control घ BDNF

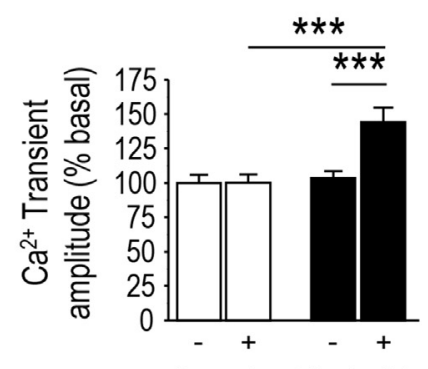

Prucalopride $1 \mu \mathrm{M}$

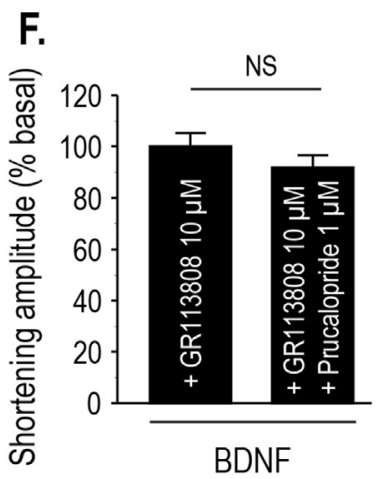

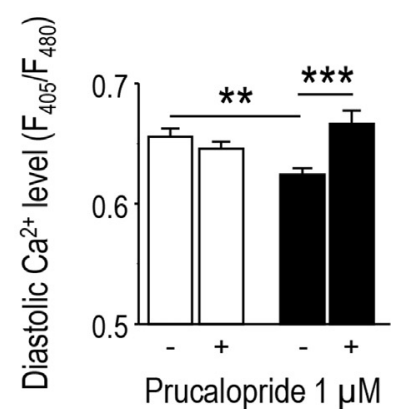

Prucalopride $1 \mu \mathrm{M}$

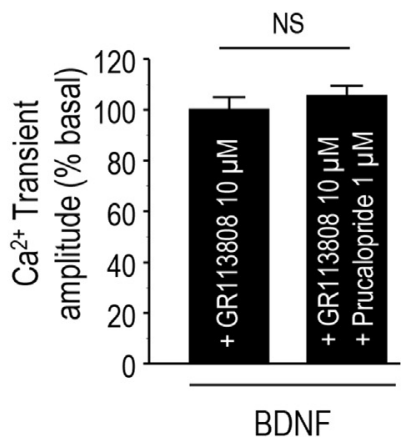


also known to be silent [7] suggesting additional roles of p11 in the former cavity in normal conditions. In this study, we considered several features of ECC (i.e. $\mathrm{Ca}^{2+}$ transient and cell shortening) with or without prucalopride stimulation as a functional read out of the activation of the $5-\mathrm{HT}_{4} \mathrm{R}$ pathway. In normal healthy LV-FW cardiomyocytes, activation of the $5-\mathrm{HT}_{4} \mathrm{R}$ pathway by prucalopride $(1 \mu \mathrm{M})$ stimulation had no effect on cardiac ECC (Fig. 1C, upper and lower panels). This absence of $5-\mathrm{HT}_{4} \mathrm{R}$ signaling in healthy cells may be due to the concomitant low expression of $\mathrm{p} 11$.

\subsection{Acute incubation with BDNF induces a $5-H T_{4} R$-mediated positive inotropic response associated with spontaneous diastolic $\mathrm{Ca}^{2+}$ waves}

Considering the low expression of p11 in physiological conditions, we assessed the potential modulatory role of p11 induction on the $5-\mathrm{HT}_{4} \mathrm{R}$ pathway in the healthy heart. LV-FW cardiomyocytes were incubated with BDNF ( $50 \mathrm{ng} / \mathrm{ml}$ ) for $8 \mathrm{~h}$ as previously described to induce a substantial increase of $\mathrm{p} 11$ protein expression [23] (Fig. 2). Incubation with BDNF at $50 \mathrm{ng} / \mathrm{ml}$ significantly increased p11 protein expression by $51.2 \pm 8.7 \%(p<0.05)$ compared to untreated cells (Fig. 2A). We then evaluated the effects of elevated p11 expression on cardiac ECC (Fig. 2B-E). p11 induction by BDNF revealed a positive inotropic response to $5-\mathrm{HT}_{4} \mathrm{R}$ stimulation in healthy LV-FW cardiomyocytes. Indeed, we observed that $5-\mathrm{HT}_{4} \mathrm{R}$ stimulation by prucalopride induced a strong inotropic response in BDNF-treated cardiomyocytes characterized by an increase of $79.9 \pm 10.5 \%$ ( $v s$. prucalopride alone, $p<0.001$ ) and $58.4 \pm 10.5 \%$ ( $v s$. BDNF alone, $p<0.001$ ) in sarcomere shortening compared to control cardiomyocytes $(6.5 \pm 7.8 \%$ prucalopride alone vs. basal, NS) (Fig. 2C, left panel). It is worth noting that BDNF itself increased SL shortening by $28.0 \pm 7.8 \%(p<0.05)$ compared to control basal (Fig. 2C, left panel). Similarly, prucalopride increased $\mathrm{Ca}^{2+}$ transient amplitude in cells treated with BDNF by $44.0 \pm 10.5 \%$ (vs. prucalopride alone, $p<0.001$ ) and $41.0 \pm 10.5 \%$ (vs. BDNF alone, $p<0.001$ ) compared to untreated cardiomyocytes $(3.3 \pm 4.9 \%$ prucalopride alone vs. basal, NS) (Fig. 2C, right panel). Diastolic $\mathrm{Ca}^{2+}$ level was also increased in BDNF-treated myocytes challenged to prucalopride compared to prucalopride alone or BDNF alone $(0.667 \pm 0.011 v s$., respectively, $0.646 \pm 0.006, p<0.001$ and $0.624 \pm 0.005, p<0.001$ ) (Fig. 2D). Interestingly, BDNF significantly decreased diastolic $\mathrm{Ca}^{2+}$ level compared to untreated cells in basal conditions $(0.624 \pm 0.005$ vs. $0.656 \pm 0.007, p<0.01) . \mathrm{Ca}^{2+}$ reuptake as indexed by $\mathrm{Ca}^{2+}$ transient decay was not modified by p11 induction following 5- $\mathrm{HT}_{4} \mathrm{R}$ stimulation (Fig. S1A).

Interestingly, 5- $\mathrm{HT}_{4} \mathrm{R}$-mediated enhancement of cardiac ECC was associated with a high propensity to trigger proarrhythmogenic $\mathrm{Ca}^{2+}$ waves during the diastolic phase in BDNF-treated myocytes compared to other conditions $(62.5 \pm 10.3 \%$ cells exhibiting diastolic $\mathrm{Ca}^{2+}$ waves vs. $12.5 \pm 7.5 \%$ prucalopride alone, $p<0.001$ and vs. $15.0 \pm 6.5 \%$ BDNF alone, $p<0.001$ ) (Fig. 2E).

The prucalopride-induced positive inotropic response encountered after $\mathrm{p} 11$ induction was abolished in presence of the specific $5-\mathrm{HT}_{4} \mathrm{R}$ blocker, GR113808 $(10 \mu \mathrm{M})$, confirming the $5-\mathrm{HT}_{4} \mathrm{R}$ pathway involvement in our model (Fig. 2F).

\subsection{Chronic imipramine treatment induces cardiomyocyte $p 11$ expression}

As several antidepressants have been shown to increase BDNF levels and p11 mRNA expression [19,28], we sought to determine whether chronic treatment with the tricyclic antidepressant (TCA) imipramine would modulate cardiac expression of p11 (Fig. 3). Three weeks treatment with imipramine induced a significant increase by $26.0 \pm 5.0 \%$ of p1 1 mRNA expression in LV-FW cardiomyocytes compared to animals treated with saline $(1.26 \pm 0.05$ vs. $1.00 \pm 0.02$, fold change, $p<0.01$ ) (Fig. $3 \mathrm{~A}$ ). Although it did not reach significance $(p=0.11)$, levels of $\mathrm{p} 11$ protein were increased by $13.6 \pm 5.6 \%$ in LV-FW cardiomyocytes after imipramine treatment compared to untreated animals (Fig. 3B). On the other hand, as imipramine is a non-selective monoamine reuptake inhibitor we assessed the effects of chronic imipramine treatment on $\beta 1$-adrenergic receptor expression. We observed that chronic treatment with imipramine did not affect $\beta 1$-adrenergic receptor expression (Fig. 3C).

\subsection{Imipramine treatment unravels a $5-H T_{4} R$-mediated positive inotropic response associated with proarrhythmogenic diastolic $\mathrm{Ca}^{2+}$ waves}

We then assessed the effects of p11 induction by imipramine treatment on cardiac ECC. Induction of p11 by chronic treatment with imipramine was associated with $5-\mathrm{HT}_{4} \mathrm{R}$-mediated enhancement of cardiac ECC similarly to that observed with the use of BDNF (Fig. 4). A remarkable positive inotropic effect was observed in LV-FW myocytes freshly isolated from imipramine-treated animals following prucalopride challenge (Fig. 4A). Indeed, in these cells, prucalopride stimulation induced an increase of $46.1 \pm 5.9 \%$ (vs. prucalopride alone, $p<0.001$ ) and $61.6 \pm 5.9 \%$ (vs. basal in imipramine-treated animals, $p<0.001$ ) in sarcomere shortening compared to LV-FW cardiomyocytes from vehicle-treated animals $(6.5 \pm 7.8 \%$ prucalopride alone $v s$. basal, NS) (Fig. 4B, left panel).

Similarly, in cardiomyocytes isolated from imipramine-treated animals, prucalopride increased $\mathrm{Ca}^{2+}$ transient amplitude by $19.4 \pm 4.9 \%$ (vs. prucalopride alone, $p<0.01$ ) and $38.0 \pm 4.9 \%$ (vs. basal in imipramine-treated animals, $p<0.001)$ compared to cardiomyocytes from vehicle-treated animals ( $13.1 \pm 3.7 \%$ prucalopride alone vs. basal, NS) (Fig. 4B, right panel). In addition, in cardiomyocytes isolated from imipramine-treated animals, diastolic $\mathrm{Ca}^{2+}$ level increased compared to prucalopride or imipramine alone (respectively $0.697 \pm 0.008 v s$. $0.677 \pm 0.006, p=0.057$ or $0.674 \pm 0.009, p<0.05$ ) (Fig. 4C). Similarly to BDNF treatment, no effect on $\mathrm{Ca}^{2+}$ transient decay was observed after imipramine treatment (Fig. S1B).

Interestingly, as previously observed with BDNF, chronic treatment with imipramine induced a high propensity of LV-FW cardiomyocytes to trigger diastolic $\mathrm{Ca}^{2+}$ events compared to other conditions $\left(52.0 \pm 17.0 \%\right.$ cells exhibiting diastolic $\mathrm{Ca}^{2+}$ waves vs. $20.5 \pm 2.3 \%$ prucalopride alone, $p<0.01$ or $v s .2 .1 \pm 2.1 \%$ basal in imipramine-treated animals, $p<0.001$ ) (Fig. 4D). In a striking way, this propensity observed after imipramine treatment was similar

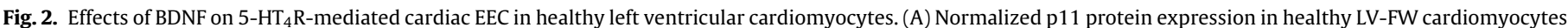

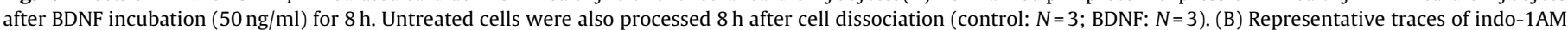

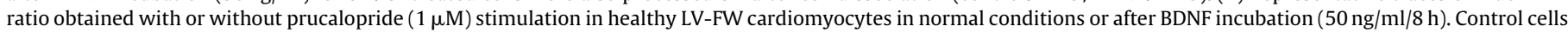

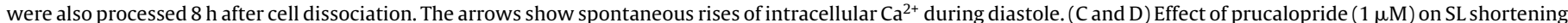

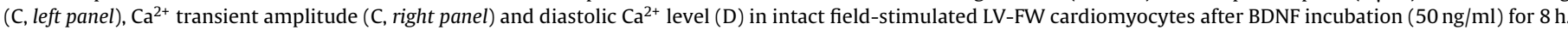

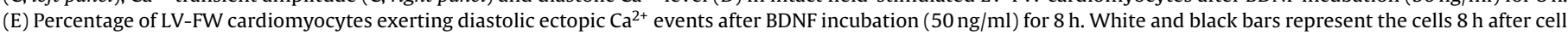

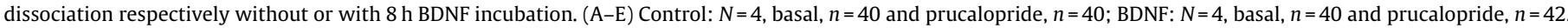

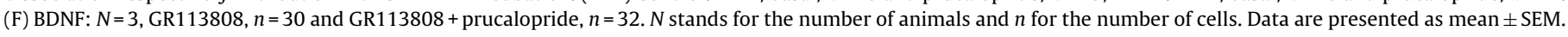
$*, * *, * * * p<0.05, p<0.01, p<0.001$. 
A.

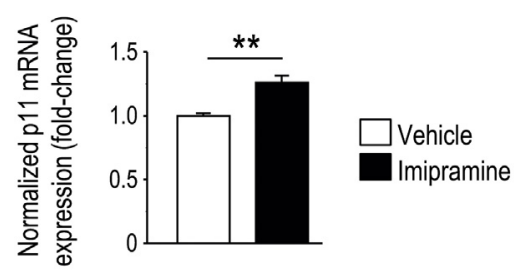

B.

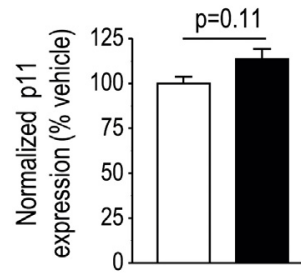

$10 \mathrm{kDa}$ -

$55 \mathrm{kDa}$ -

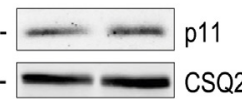

C.

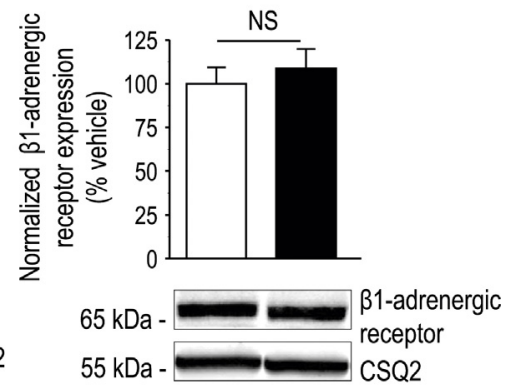

Fig. 3. Effects of imipramine on $\mathrm{p} 11$ expression in healthy left ventricular cardiomyocytes. (A-C) Normalized p11 mRNA expression (A) (control: $N=3$; imipramine: $N=3$ ) and p11 (B) or $\beta 1$-adrenergic receptor proteins (C) expressions (control: $N=4$; imipramine: $N=4$ ) in healthy LV-FW cardiomyocytes from rats treated with saline or imipramine $(10 \mathrm{mg} / \mathrm{kg} / \mathrm{day} / \mathrm{ip})$ for 21 days. ${ }^{* *} p<0.01$.

to another proarrhythmogenic context obtained after $\beta$-adrenergic receptors stimulation with non-selective $\beta$-agonist, isoprenaline $(10 \mathrm{nM})\left(76.0 \pm 9.3 \%\right.$ cells exhibiting diastolic $\mathrm{Ca}^{2+}$ waves $)$ (Fig. 4D).

\subsection{Chronic BDNF treatment induces a sustained chronotropic response to $5-\mathrm{HT}_{4} \mathrm{R}$ stimulation in healthy animals}

Regarding the deleterious effects on $\mathrm{Ca}^{2+}$ homeostasis caused by $\mathrm{p} 11$ induction and $5-\mathrm{HT}_{4} \mathrm{R}$ stimulation in vitro, we evaluated whether p11 induction would modulate heart function through $5-\mathrm{HT}_{4} \mathrm{R}$ pathway enhancement in vivo. ECG were recorded in free-moving conscious animals allowing heart rate measurement (obtained by RR intervals assessment) in healthy adult rats treated with BDNF for 14 days and undergoing prucalopride injection before and after the treatment (day 0 and day 14) (Fig. 5). Before and after BDNF treatment, an increased heart rate was observed during $25 \mathrm{~min}$ after prucalopride injection. This effect may be due to injection-dependent stress or to potential non-cardiac effects of prucalopride resulting in an increase of heart rate (Fig. 5A).

On the other hand, 2 weeks of BDNF treatment allowed a sustained chronotropic response to prucalopride injection for $60 \mathrm{~min}$ in the same rats compared to before treatment $(417 \pm 2$ beats $/ \mathrm{min}$ $v s .393 \pm 5$ beats $/ \mathrm{min}, p<0.001$ ) (Fig. $5 \mathrm{~B}$, left panel). Indeed, whereas heart rate returned to a physiological range before BDNF treatment by 25 min following prucalopride injection, a significant sustained increase in heart rate was observed beyond $25 \mathrm{~min}$ in rats after they were treated with BDNF ( $406 \pm 2$ beats/min vs. $366 \pm 4$ beats $/ \mathrm{min}$, $p<0.001$ ) (Fig. 5B, right panel).

\section{Discussion}

The physiopathological cardiac effects of the $5-\mathrm{HT}_{4} \mathrm{R}$ pathway remain poorly understood. The $5-\mathrm{HT}_{4} \mathrm{R}$ partner $\mathrm{p} 11$ has a clear role in $5-\mathrm{HT}_{4} \mathrm{R}$ signaling in the mouse brain $[12,19,23]$ but its role in the cardiac tissue had not been investigated yet. Here, we have demonstrated that p11 may act as a critical modulator of $\mathrm{Ca}^{2+}$ handling and ECC in rat ventricular cardiomyocytes through the activation

A.

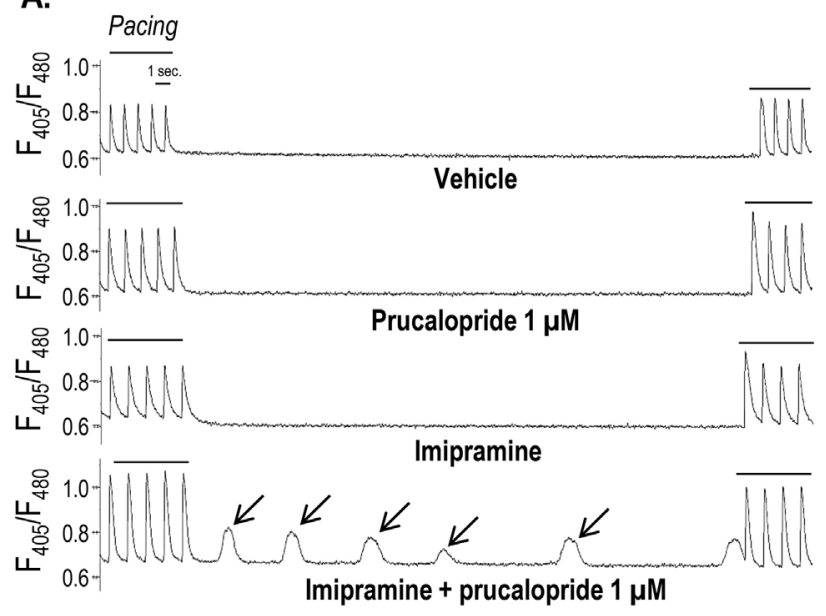

B.
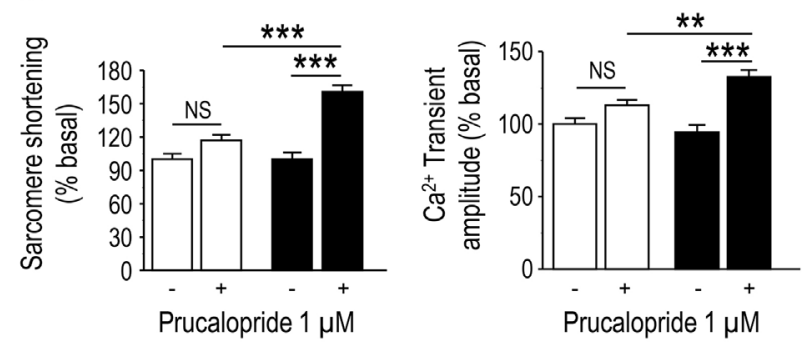

Vehicle

C.

D.
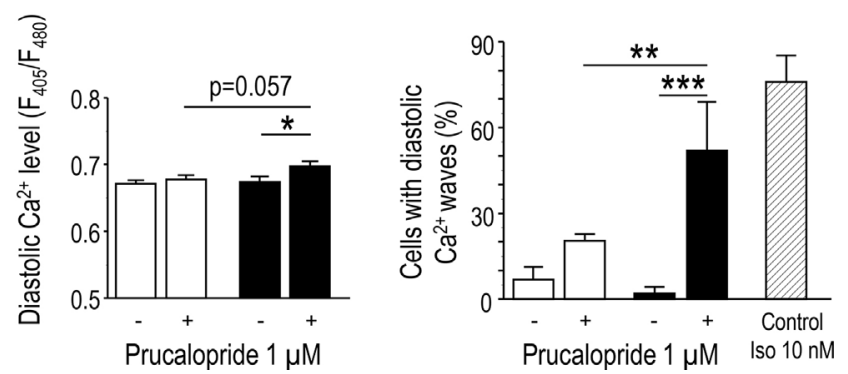

Fig. 4. Effects of imipramine on $5-\mathrm{HT}_{4} \mathrm{R}$-mediated cardiac ECC in healthy left ventricular cardiomyocytes. (A) Representative traces of indo-1AM ratio obtained with or without prucalopride $(1 \mu \mathrm{M})$ stimulation in healthy LV-FW cardiomyocytes freshly isolated from rats treated with saline or imipramine $(10 \mathrm{mg} / \mathrm{kg} / 21$ days/ip). The arrows show spontaneous rises of intracellular $\mathrm{Ca}^{2+}$ during diastole. (B and C) Effect of prucalopride $(1 \mu \mathrm{M})$ on SL shortening (B, left panel), $\mathrm{Ca}^{2+}$ transient amplitude (B, right panel) and diastolic $\mathrm{Ca}^{2+}$ level $(\mathrm{C})$ in intact field-stimulated LV-FW cardiomyocytes from rats treated with imipramine $(10 \mathrm{mg} / \mathrm{kg} / \mathrm{day} / \mathrm{ip})$ or saline for 21 days. (D) Percentage of LV-FW cardiomyocytes exerting diastolic $\mathrm{Ca}^{2+}$ ectopic events isolated from rats treated with imipramine $(10 \mathrm{mg} / \mathrm{kg} / \mathrm{day} / \mathrm{ip})$ or saline for 21 days or isolated from healthy rats and challenged with $10 \mathrm{nM}$ isoprenaline ( $n=50$ cells). Data are presented as mean \pm SEM. $N$ stands for the number of animals and $n$ for the number of cells: control: $N=4$, basal, $n=43$ and prucalopride, $n=44$; imipramine: $N=4$, basal, $n=44$ and prucalopride, $n=43$. ${ }^{* * *, * * *} p<0.05$, $p<0.01, p<0.001$.

of the cardiac $5-\mathrm{HT}_{4} \mathrm{R}$ pathway. Although low levels of $\mathrm{p} 11$ expression may be insufficient to induce $5-\mathrm{HT}_{4} \mathrm{R}$ activity in physiological conditions, we have unraveled conditions in which this pathway is enhanced.

In our study, we considered several parameters of $\mathrm{Ca}^{2+}$ handling obtained with prucalopride stimulation as a read-out of the $5-\mathrm{HT}_{4} \mathrm{R}$ pathway activation. Based on the literature, assessment of the cellular expression or localization of the cardiac $5-\mathrm{HT}_{4} \mathrm{R}$ is strongly limited due to technical issues related to the low density of the receptors. We have therefore concluded that cardiac 


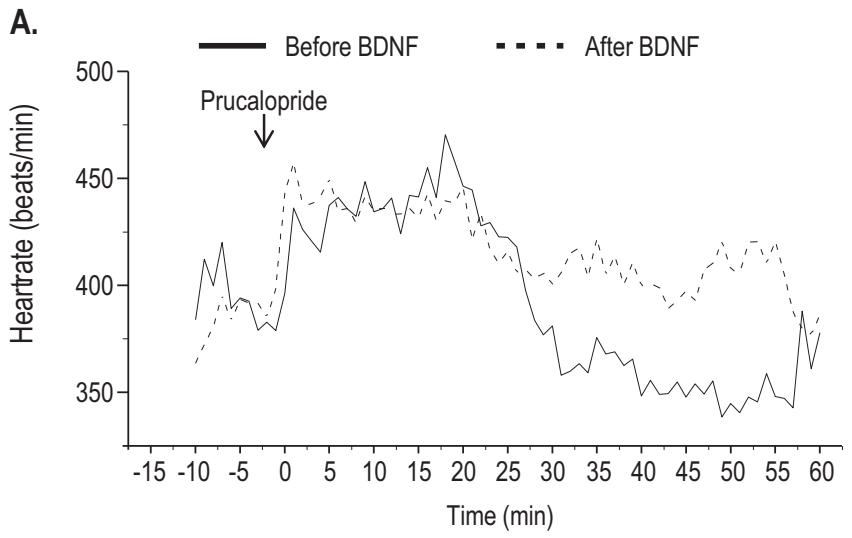

B.
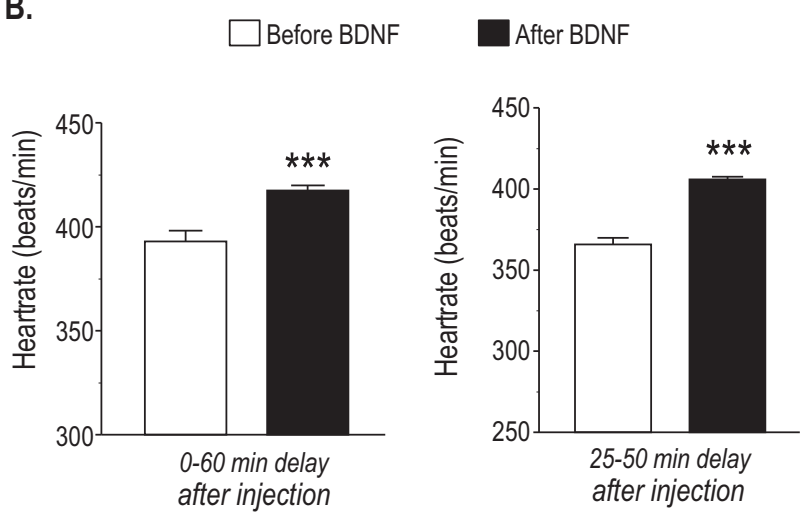

Fig. 5. Effects of BDNF treatment on $5-\mathrm{HT}_{4} \mathrm{R}$-mediated cardiac function in healthy hearts. (A) Effect of prucalopride injection $(0.1 \mathrm{mg} / \mathrm{kg} / \mathrm{ip})$ before and after BDNF treatment $(180 \mathrm{ng} / \mathrm{day} / 14$ days/sc) on heart rate. (B) Averaged heart rates during $60 \mathrm{~min}$ (left panel) or 25-50 min (right panel) following prucalopride injection before and after BDNF treatment. The arrow represents the time of injection. Straight and dashed lines, respectively, represent heart rates before and after BDNF treatment. Data are presented as mean \pm SEM. $N=6$ animals. ${ }^{* * *} p<0.001$.

5- $\mathrm{HT}_{4} \mathrm{R}$ pathway-mediated effects on $\mathrm{Ca}^{2+}$ handling are a feature of cardiomyocyte expression of $\mathrm{p} 11$, responses to prucalopride stimulation and the role of $\mathrm{p} 11$ in the $5-\mathrm{HT}_{4} \mathrm{R}$ translocation previously described in the literature [12]. Taking advantage of the rodent model in which the $5-\mathrm{HT}_{4} \mathrm{R}$ pathway is functionally silent in the ventricle in normal conditions, we now demonstrate that p11 induction in healthy cardiomyocytes increases the activity of the cardiac $5-\mathrm{HT}_{4} \mathrm{R}$ pathway and thus modulates $\mathrm{Ca}^{2+}$ flux in these cells.

BDNF induces p11 expression but also exerts direct effects on the heart, especially in coronary heart disease [29,30]. BDNF acts mainly via the tropomyosin-related kinase $B(\operatorname{trkB})$ receptor [31]. Indeed, in a recent study, Feng et al. showed that BDNF was active on rodent cardiomyocytes through the trkB pathway activation [32]. According to these evidences, we hypothesized that increasing BDNF levels may modulate cardiac p11-dependent $5-\mathrm{HT}_{4} \mathrm{R}$ signaling. Although, in rodents, the $5-\mathrm{HT}_{4} \mathrm{R}$ pathway remains to be silent at the ventricular level in non-pathological states in contrast with findings in failing animals [9], BDNF-dependent p11 induction exerted remarkable functional effects on cardiac ECC following 5 - $\mathrm{HT}_{4} \mathrm{R}$ stimulation.

The elevated p11 expression induced $5-\mathrm{HT}_{4} \mathrm{R}$ activity as a possible threshold enabling a global effect on $\mathrm{Ca}^{2+}$ handling at the cellular level even in physiological conditions. This enhancement observed at the cellular level was encountered in vivo as the $5-\mathrm{HT}_{4} \mathrm{R}$ pathway stimulation impacted heart rate after BDNF treatment. As $5-\mathrm{HT}_{4} \mathrm{R}$ is the only serotonin receptor subtype expressed in the human sinoatrial node, whose stimulation leads to long-lasting tachycardia [33], BDNF may also enhance $5-\mathrm{HT}_{4} \mathrm{R}$ activity in this compartment resulting in the increased heart rate observed in our study. We have shown that $5-\mathrm{HT}_{4} \mathrm{R}$-mediated enhancement of cardiac ECC was associated with a high propensity to trigger proarrhythmogenic diastolic $\mathrm{Ca}^{2+}$ events at the cellular level which are likely to be a cause of delayed afterdepolarizations (DADs) that may further trigger ventricular arrhythmias and lead to sudden cardiac death [34].

The commonly used TCA imipramine promoted similar effects on $\mathrm{p} 11$ expression and $5-\mathrm{HT}_{4} \mathrm{R}$-related $\mathrm{Ca}^{2+}$ handling. Imipramine was previously shown to increase p11 mRNA expression in the mouse forebrain and cortex [19]. Interestingly, it exerts a similar pattern of p11 mRNA induction in the heart and in the brain ( $30 \%$ increase). However, based on the literature, p11 induction by imipramine at the protein level has yet to be investigated. Herein, we have shown that imipramine may increase cardiac p11 expression leading to an enhancement of $5-\mathrm{HT}_{4} \mathrm{R}$-mediated $\mathrm{Ca}^{2+}$ handling in ventricular cardiomyocytes. Considering the features of cardiac ECC after $5-\mathrm{HT}_{4} \mathrm{R}$ stimulation in animals treated with imipramine, we assumed that $\mathrm{I}_{\mathrm{CaL}}$ activity is largely responsible for the modulation of $\mathrm{Ca}^{2+}$ handling as the $5-\mathrm{HT}_{4} \mathrm{R}$ stimulation is known to strongly enhance LTCC activity [11]. Enhanced LTCC activity may induce intracellular $\mathrm{Ca}^{2+}$ overload and cause elevated diastolic $\left[\mathrm{Ca}^{2+}\right]_{i}$. Moreover, supported by a body of evidence transposable to the cardiac 5- $\mathrm{HT}_{4} \mathrm{R}$ pathway [35-37], a potential role of leaky RyR2 in the occurrence of diastolic aberrant $\mathrm{Ca}^{2+}$ release such as $\mathrm{Ca}^{2+}$ waves is expected to be preponderant in our model.

Although BDNF induced a stronger increase of $\mathrm{p} 11$ protein than imipramine, the effects of the $5-\mathrm{HT}_{4} \mathrm{R}$ pathway in both conditions seemed relatively similar as observed by cardiac $\mathrm{Ca}^{2+}$ handling and ECC, suggesting a non-related-p11 mechanism involved with imipramine treatment. As imipramine is a non-selective monoamine reuptake inhibitor, the inhibition of norepinephrine reuptake may potentiate $5-\mathrm{HT}_{4} \mathrm{R}$ activity possibly by increasing the desensitization of $\beta$-adrenergic receptors due to chronic stimulation without affecting their expression as demonstrated here. Hence, chronic stimulation of both PKA-related pathways $\left(5-\mathrm{HT}_{4} \mathrm{R}\right.$ and $\beta$-adrenergic pathways) may induce remodeling of $\mathrm{Ca}^{2+}$ handling key actors in the heart.

Although the literature is quite controversial whether imipramine increases [38-40] or not [41] BDNF levels, it has been shown to activate trkB signaling independently from BDNF by physically interacting with the receptor [42]. This supports a potential similar mechanism in our study. While the $5-\mathrm{HT}_{4} \mathrm{R}$ pathway is functionally active in the normal human heart at both atrial and ventricular levels, the present data may be relevant assuming that the $5-\mathrm{HT}_{4} \mathrm{R}$ response would be enhanced by $\mathrm{p} 11$ induction due to antidepressant treatments $[43,44]$.

Depression and cardiovascular disease have been reciprocally linked but the physiopathological features are not clearly defined. These diseases have been predicted to be the two most severe mortality factors in the coming years [45]. Selective serotonin reuptake inhibitors (SSRI), noradrenaline reuptake inhibitors or TCA are the mainstream medications for the treatment of depression [46]. Contrary to their significant beneficial effects on depression symptoms, antidepressant treatments may also induce cardiac toxicity or rhythmic disorders such as prolonged QT interval $[47,48]$, a potential substrate for arrhythmias. BDNF levels have been shown to be restored following chronic treatment with several classes of antidepressants [38,39,49] as well as p11 levels [19]. Here, we suggest that during antidepressant treatment, p11 induction by TCA or BDNF increases cardiac $5-\mathrm{HT}_{4} \mathrm{R}$ pathway activity, potentially overstimulated due to 5 -HT-reuptake inhibition carried out by antidepressant drugs. Thus, sustained $5-\mathrm{HT}_{4} \mathrm{R}$ stimulation in cardiomyocytes enhancing $\mathrm{Ca}^{2+}$ handling and generating diastolic $\mathrm{Ca}^{2+}$ waves could provide conditions for cardiac remodeling 
overtime and occurrence of arrhythmias which may explain and/or contribute to the antidepressant-related cardiotoxicity.

\section{Conclusion}

This study is the first to show a role for p11 in the $5-\mathrm{HT}_{4} \mathrm{R}$ mediated modulation of cardiac $\mathrm{Ca}^{2+}$ handling and ECC in the myocardium. Induction of p11 protein by several factors involved in depression management such as the neurotrophin BDNF or the TCA imipramine unravels strong $5-\mathrm{HT}_{4} \mathrm{R}$-mediated effects on $\mathrm{Ca}^{2+}$ handling associated with diastolic $\mathrm{Ca}^{2+}$ abnormalities known to be deleterious. Although the physiological activity of the cardiac $5-\mathrm{HT}_{4} \mathrm{R}$ pathway between human and rodents still remains a point of discrepancy, these results obtained in a rodent model may interestingly translate to the effects of a potential p11-dependent enhanced $5-\mathrm{HT}_{4} \mathrm{R}$ pathway on $\mathrm{Ca}^{2+}$ handling in humans treated with TCA. Considering the emerging links between antidepressants, BDNF, p11 and 5- $\mathrm{HT}_{4} \mathrm{R}$, our data suggest that the modulation of $\mathrm{Ca}^{2+}$ handling in ventricular cardiomyocytes through enhanced $5-\mathrm{HT}_{4} \mathrm{R}$ pathway and $\mathrm{p} 11$ induction could partly explain the antidepressant-mediated cardiotoxicity.

\section{Conflicts of interest}

The authors declare no conflicts of interest.

\section{Acknowledgments}

This work was supported by funding from the French Institut National de la Santé Et de la Recherche Médicale (INSERM), 'Fondation de France (2013 00038586)', and the French Fondation pour la Recherche Médicale (FRM).

\section{References}

[1] D.M. Bers, Cardiac excitation-contraction coupling, Nature 415 (2002) 198-205, http://dx.doi.org/10.1038/415198a.

[2] A. Lymperopoulos, G. Rengo, W.J. Koch, Adrenergic nervous system in heart failure: pathophysiology and therapy, Circ. Res. 113 (2013) 739-753, http:// dx.doi.org/10.1161/CIRCRESAHA.113.300308.

[3] W.H. Frishman, P. Grewall, Serotonin and the heart, Ann. Med. 32 (2000) 195-209.

[4] T. Brattelid, E. Qvigstad, J.A. Lynham, P. Molenaar, H. Aass, O. Geiran, et al., Functional serotonin 5-HT4 receptors in porcine and human ventricular myocardium with increased 5-HT4 mRNA in heart failure, Naunyn. Schmiedebergs Arch. Pharmacol. 370 (2004) 157-166, http://dx.doi.org/10. 1007/s00210-004-0963-0.

[5] F. Lezoualc'h, K. Steplewski, L. Sartiani, A. Mugelli, R. Fischmeister, A. Bril, Quantitative mRNA analysis of serotonin 5-HT4 receptor isoforms, calcium handling proteins and ion channels in human atrial fibrillation, Biochem. Biophys. Res. Commun. 357 (2007) 218-224, http://dx.doi.org/10.1016/j.bbrc. 2007.03.124.

[6] D. Pau, A.J. Workman, K.A. Kane, A.C. Rankin, Electrophysiological and arrhythmogenic effects of 5-hydroxytryptamine on human atrial cells are reduced in atrial fibrillation, J. Mol. Cell. Cardiol. 42 (2007) 54-62, doi:10.1016/j.yjmcc.2006.08.007.

[7] S. Läer, F. Remmers, H. Scholz, B. Stein, F.U. Müller, J. Neumann, Receptor mechanisms involved in the 5-HT-induced inotropic action in the rat isolated atrium, Br. J. Pharmacol. 123 (1998) 1182-1188, http://dx.doi.org/10.1038/sj. bjp.0701702.

[8] S.W. Watts, S.F. Morrison, R.P. Davis, S.M. Barman, Serotonin and blood pressure regulation, Pharmacol. Rev. 64 (2012) 359-388, http://dx.doi.org/10. 1124/pr.111.004697.

[9] E. Qvigstad, T. Brattelid, I. Sjaastad, K.W. Andressen, K.A. Krobert, J.A. Birkeland, et al., Appearance of a ventricular 5-HT4 receptor-mediated inotropic response to serotonin in heart failure, Cardiovasc. Res. 65 (2005) 869-878, http://dx.doi.org/10.1016/j.cardiores.2004.11.017.
[10] T. Brattelid, E. Qvigstad, L.R. Moltzau, S.V.S. Bekkevold, D.L. Sandnes, J.A.K. Birkeland, et al., The cardiac ventricular 5-HT4 receptor is functional in late foetal development and is reactivated in heart failure, PLoS One 7 (2012) e45489, http://dx.doi.org/10.1371/journal.pone.0045489.

[11] J.A.K. Birkeland, F. Swift, N. Tovsrud, U. Enger, P.K. Lunde, E. Qvigstad, et al., Serotonin increases L-type Ca2+ current and SR Ca2+ content through 5-HT4 receptors in failing rat ventricular cardiomyocytes, Am. J. Physiol. Heart Circ. Physiol. 293 (2007) H2367-H2376, http://dx.doi.org/10.1152/ajpheart.01375. 2006.

[12] J.L. Warner-Schmidt, M. Flajolet, A. Maller, E.Y. Chen, H. Qi, P. Svenningsson, et al., Role of p11 in cellular and behavioral effects of 5-HT4 receptor stimulation, J. Neurosci. Off. J. Soc. Neurosci. 29 (2009) 1937-1946, http://dx. doi.org/10.1523/JNEUROSCI. 5343-08.2009.

[13] U. Rescher, V. Gerke, S100A10/p11: family, friends and functions, Pflüg Arch. Eur. J. Physiol. 455 (2008) 575-582, http://dx.doi.org/10.1007/s00424-0070313-4.

[14] C.J. Saris, T. Kristensen, P. D’Eustachio, L.J. Hicks, D.J. Noonan, T. Hunter, et al., cDNA sequence and tissue distribution of the mRNA for bovine and murine p11, the S100-related light chain of the protein-tyrosine kinase substrate p36 (calpactin I), J. Biol. Chem. 262 (1987) 10663-10671.

[15] P.A. Madureira, A.P. Surette, K.D. Phipps, M.A.S. Taboski, V.A. Miller, D.M. Waisman, The role of the annexin A2 heterotetramer in vascular fibrinolysis, Blood 118 (2011) 4789-4797, http://dx.doi.org/10.1182/blood-2011-06334672.

[16] I. Brandherm, J. Disse, D. Zeuschner, V. Gerke, cAMP-induced secretion of endothelial von Willebrand factor is regulated by a phosphorylation/dephosphorylation switch in annexin A2, Blood 122 (2013) 1042-1051, http://dx.doi.org/10.1182/blood-2012-12-475251.

[17] S.F.J. van de Graaf, J.G.J. Hoenderop, D. Gkika, D. Lamers, J. Prenen, U. Rescher, et al., Functional expression of the epithelial $\mathrm{Ca}(2+)$ channels (TRPV5 and TRPV6) requires association of the S100A10-annexin 2 complex, EMBO J. 22 (2003) 1478-1487, http://dx.doi.org/10.1093/emboj/cdg162.

[18] K. Okuse, M. Malik-Hall, M.D. Baker, W.-Y.L. Poon, H. Kong, M.V. Chao, et al., Annexin II light chain regulates sensory neuron-specific sodium channel expression, Nature 417 (2002) 653-656, http://dx.doi.org/10.1038/ nature00781.

[19] P. Svenningsson, K. Chergui, I. Rachleff, M. Flajolet, X. Zhang, M. El Yacoubi, et al., Alterations in 5-HT1B receptor function by p11 in depression-like states, Science 311 (2006) 77-80, http://dx.doi.org/10.1126/science.1117571.

[20] R. Pawliczak, M.J. Cowan, X. Huang, U.B. Nanavaty, S. Alsaaty, C. Logun, et al., p11 expression in human bronchial epithelial cells is increased by nitric oxide in a cGMP-dependent pathway involving protein kinase G activation, J. Biol. Chem. 276 (2001) 44613-44621, http://dx.doi.org/10.1074/jbc.M104993200.

[21] S. Akiba, R. Hatazawa, K. Ono, M. Hayama, H. Matsui, T. Sato, Transforming growth factor-alpha stimulates prostaglandin generation through cytosolic phospholipase $\mathrm{A}(2)$ under the control of p11 in rat gastric epithelial cells, Br. J. Pharmacol. 131 (2000) 1004-1010, http://dx.doi.org/10.1038/sj.bjp.0703637.

[22] P. Masiakowski, E.M. Shooter, Nerve growth factor induces the genes for two proteins related to a family of calcium-binding proteins in PC12 cells, Proc. Natl. Acad. Sci. U.S.A. 85 (1988) 1277-1281

[23] J.L. Warner-Schmidt, E.Y. Chen, X. Zhang, J.J. Marshall, A. Morozov, P. Svenningsson, et al., A role for p11 in the antidepressant action of brain-derived neurotrophic factor, Biol. Psychiatry 68 (2010) 528-535, http:// dx.doi.org/10.1016/j.biopsych.2010.04.029.

[24] L. Andre, J. Boissière, C. Reboul, R. Perrier, S. Zalvidea, G. Meyer, et al., Carbon monoxide pollution promotes cardiac remodeling and ventricular arrhythmia in healthy rats, Am. J. Respir. Crit. Care Med. 181 (2010) 587-595, http://dx. doi.org/10.1164/rccm.200905-07940C.

[25] L. Andre, J. Fauconnier, C. Reboul, C. Feillet-Coudray, P. Meschin, C. Farah, et al., Subendocardial increase in reactive oxygen species production affects regional contractile function in ischemic heart failure, Antioxid. Redox Signal. 18 (2013) 1009-1020, http://dx.doi.org/10.1089/ars.2012.4534.

[26] C.R. Sartori, A.S. Vieira, E.M. Ferrari, F. Langone, E. Tongiorgi, C.A. Parada, The antidepressive effect of the physical exercise correlates with increased levels of mature BDNF, and proBDNF proteolytic cleavage-related genes, p11 and tPA, Neuroscience 180 (2011) 9-18, http://dx.doi.org/10.1016/j.neuroscience. 2011.02.055.

[27] T. Brattelid, L.H. Winer, F.O. Levy, K. Liestøl, O.M. Sejersted, K.B. Andersson, Reference gene alternatives to Gapdh in rodent and human heart failure gene expression studies, BMC Mol. Biol. 11 (2010) 22, http://dx.doi.org/10.1186/ 1471-2199-11-22.

[28] Y.-S. Oh, P. Gao, K.-W. Lee, I. Ceglia, J.-S. Seo, X. Zhang, et al., SMARCA3, a chromatin-remodeling factor, is required for p11-dependent antidepressant action, Cell 152 (2013) 831-843, http://dx.doi.org/10.1016/j.cell.2013.01.014.

[29] J. Ejiri, N. Inoue, S. Kobayashi, R. Shiraki, K. Otsui, T. Honjo, et al., Possible role of brain-derived neurotrophic factor in the pathogenesis of coronary artery disease, Circulation 112 (2005) 2114-2120, http://dx.doi.org/10.1161/ CIRCULATIONAHA.104.476903.

[30] S. Okada, M. Yokoyama, H. Toko, K. Tateno, J. Moriya, I. Shimizu, et al., Brain-derived neurotrophic factor protects against cardiac dysfunction after myocardial infarction via a central nervous system-mediated pathway, Arterioscler. Thromb. Vasc. Biol. 32 (2012) 1902-1909, http://dx.doi.org/10. 1161/ATVBAHA.112.248930.

[31] R. Klein, V. Nanduri, S.A. Jing, F. Lamballe, P. Tapley, S. Bryant, et al., The trkB tyrosine protein kinase is a receptor for brain-derived neurotrophic factor and neurotrophin-3, Cell 66 (1991) 395-403. 
[32] N. Feng, S. Huke, G. Zhu, C.G. Tocchetti, S. Shi, T. Aiba, et al., Constitutive BDNF/TrkB signaling is required for normal cardiac contraction and relaxation, Proc. Natl. Acad. Sci. U.S.A. 112 (2015) 1880-1885, http://dx.doi. org/10.1073/pnas.1417949112.

[33] A.J. Kaumann, F.O. Levy, 5-hydroxytryptamine receptors in the human cardiovascular system, Pharmacol. Ther. 111 (2006) 674-706.

[34] M. Yano, Y. Ikeda, M. Matsuzaki, Altered intracellular Ca2+ handling in heart failure, J. Clin. Invest. 115 (2005) 556-564, http://dx.doi.org/10.1172/ JCI24159.

[35] S.O. Marx, S. Reiken, Y. Hisamatsu, T. Jayaraman, D. Burkhoff, N. Rosemblit, et al., PKA phosphorylation dissociates FKBP12.6 from the calcium release channel (ryanodine receptor): defective regulation in failing hearts, Cell 101 (2000) 365-376

[36] S. Robert, M. Maillet, E. Morel, J.-M. Launay, R. Fischmeister, L. Mercken, et al. Regulation of the amyloid precursor protein ectodomain shedding by the 5-HT4 receptor and Epac, FEBS Lett. 579 (2005) 1136-1142, http://dx.doi.org/ 10.1016/j.febslet.2005.01.010.

[37] L. Pereira, M. Métrich, M. Fernández-Velasco, A. Lucas, J. Leroy, R. Perrier et al., The cAMP binding protein Epac modulates Ca2+ sparks by a $\mathrm{Ca} 2+/$ calmodulin kinase signalling pathway in rat cardiac myocytes, J. Physiol. 583 (2007) 685-694, http://dx.doi.org/10.1113/jphysiol.2007. 133066.

[38] K. Takano, H. Yamasaki, K. Kawabe, M. Moriyama, Y. Nakamura, Imipramine induces brain-derived neurotrophic factor mRNA expression in cultured astrocytes, J. Pharmacol. Sci. 120 (2012) 176-186.

[39] G.Z. Réus, M.A.B. Dos Santos, H.M. Abelaira, K.F. Ribeiro, F. Petronilho, F. Vuolo, et al., Imipramine reverses alterations in cytokines and BDNF levels induced by maternal deprivation in adult rats, Behav. Brain Res. 242 (2013) 40-46, http://dx.doi.org/10.1016/j.bbr.2012.11.044.

[40] S. Yasuda, M. Yoshida, H. Yamagata, Y. Iwanaga, H. Suenaga, K. Ishikawa, et al., Imipramine ameliorates pain-related negative emotion via induction of brain-derived neurotrophic factor, Cell. Mol. Neurobiol. 34 (2014) 1199-1208, http://dx.doi.org/10.1007/s10571-014-0097-y.

[41] J.D. Van Hoomissen, H.O. Chambliss, P.V. Holmes, R.K. Dishman, Effects of chronic exercise and imipramine on mRNA for BDNF after olfactory bulbectomy in rat, Brain Res. 974 (2003) 228-235

[42] T. Saarelainen, P. Hendolin, G. Lucas, E. Koponen, M. Sairanen, E. MacDonald et al., Activation of the TrkB neurotrophin receptor is induced by antidepressant drugs and is required for antidepressant-induced behavioral effects, J. Neurosci. Off. J. Soc. Neurosci. 23 (2003) 349-357.

[43] A.J. Kaumann, L. Sanders, 5-Hydroxytryptamine causes rate-dependent arrhythmias through 5-HT4 receptors in human atrium: facilitation by chronic beta-adrenoceptor blockade, Naunyn. Schmiedebergs Arch. Pharmacol. 349 (1994) 331-337.

[44] U. Gergs, M. Baumann, A. Böckler, I.B. Buchwalow, H. Ebelt, L. Fabritz, et al., Cardiac overexpression of the human 5-HT4 receptor in mice, Am. J. Physiol. Heart Circ. Physiol. 299 (2010) H788-H798, http://dx.doi.org/10.1152/ ajpheart.00691.2009.

[45] C.J. Murray, A.D. Lopez, Alternative projections of mortality and disability by cause 1990-2020: Global Burden of Disease Study, Lancet 349 (1997) 1498-1504, http://dx.doi.org/10.1016/S0140-6736(96)07492-2.

[46] O. Berton, E.J. Nestler, New approaches to antidepressant drug discovery: beyond monoamines, Nat. Rev. Neurosci. 7 (2006) 137-151, http://dx.doi.org/ $10.1038 / \mathrm{nrn} 1846$.

[47] H.J. Witchel, J.C. Hancox, D.J. Nutt, Psychotropic drugs, cardiac arrhythmia, and sudden death, J. Clin. Psychopharmacol. 23 (2003) 58-77.

[48] M.J. Cooke, W.S. Waring, Citalopram and cardiac toxicity, Eur. J. Clin. Pharmacol. 69 (2013) 755-760, http://dx.doi.org/10.1007/s00228-0121408-1.

[49] M. Nibuya, S. Morinobu, R.S. Duman, Regulation of BDNF and trkB mRNA in rat brain by chronic electroconvulsive seizure and antidepressant drug treatments, J. Neurosci. Off. J. Soc. Neurosci. 15 (1995) 7539-7547. 